\title{
Patent Deposit as a Source of Identification of Creativity in Companies
}

\author{
Alessandra Cassol, Antonio Oliveira de Carvalho, Ivano Ribeiro \& Renato Fabiano Cintra
}

\begin{abstract}
A creative process represents the development of original solutions in the face of the perspectives of new issues and challenges arising from the ongoing changes within the companies. The present article has the purpose of understanding how patent deposits can assist in systemizing creative management in companies. Scientometrics was used as a method of research through the PatentScope and Patent Inspiration data-bases; for data analysis the Gephi 0.8.2. was used, for a 10-year research period, from 2004 to 2014. The results suggest that patents could supply to the companies supporting information for the development of systemized solutions on managing creativity. The research presents as a contribution an understanding on the use of patents as a source of information for the generation of support for managing creativity in companies. The originality of this study refers to the research in patents as a documental source for the understanding of management tools, once there is a small number of researches in Brazil in this area.
\end{abstract}

Keywords: Managing creativity, Innovation, Patent registry

Resumo: O processo criativo representa a formulação de soluções originais frente às perspectivas de novos problemas e desafios decorrentes de mudanças constantes nas empresas. Este artigo tem por objetivo compreender como patentes depositadas podem auxiliar na sistematização da gestão da criatividade em empresas. Utilizamos como método de pesquisa a cienciometria, por meio de pesquisas nas bases de dados PatentScope e Patent Inspiration, para análise dos dados foi utilizado o Gephi 0.8.2, pra análise do período pesquisado que abrangeu um período de 10 anos de 2004 a 2014. Os resultados sugerem que as patentes podem fornecer às empresas informações de apoio para o desenvolvimento de soluções de sistematização na gestão da criatividade. A pesquisa apresenta como contribuição a compreensão sobre como a utilização de patentes como fonte de informação para geração de suporte para a gestão da criatividade nas empresas. A originalidade deste estudo refere-se à pesquisa em patentes como fonte documental para compreensão de ferramentas de gestão, pois existe um pequeno número pesquisa no Brasil nesta área.

Palavras-chave: Gestão da criatividade, Inovação, Registro de patentes.

\section{Introduction}

The theme creativity in the framework of management has been increasingly under research and discussed in publications and in management during the last decades. Propositions and findings are observed in the researches of a relationship between creativity and innovation, whereby the first being considered as a driving force for the development of innovations within organizations. Creativity, in order to result in innovation and in advantages, is associated to the capacity of the organization of using and improving their own resources and procedures, resulting in an improvement to internal efficiency -exploitation- as well as in its capacity to explore, search for innovation, experiment, discover, research -exploration- (March, 1991).

Organizations owning resources considered as valuable, rare and inimitable are able to reach competitive advantage (Barney, 1991). Accordingly, organizational management guided towards the systematization of existing creativity is fundamental for the construction of enabling environments for innovation within the company. The process of managing creativity, which can, as a consequence, onset innovation, is capable of delivering a competitive edge to these companies. Nevertheless, many of them do not perceive that the registry of patents represents aspects that could be considered as allies to this management process, once they are sources of research containing countless tools and management models available for consultation. In this manner, the present article aims to understand and answer: How can patent deposits help in systemizing the process of managing creativity within companies?

Woodman, Sawyer and Griffin (1993) defined organizational creativity as the creation of a valuable, new or useful - product, service, idea, procedure or process - developed by individuals working together in a social system. For Westwood and Low (2003) creativity is part of the process of innovation, innovation representing the practical application of creative ideas, and a company is not able to innovate if it is not capable of generating creative ideas. In order to generate and sustain competitive advantages, the company is required to have the skills and capacities of creating and recreating an efficient structure and, above all, managing creativity and the consequences generated by ongoing changes. (Carvalho et al., 2016)

In this context, to systemize creativity in order that it may be improved and used by the company is of fundamental importance to the generation of innovation. Under this perspective patents that represent objects of 
practical use, suitable for application and which can deliver functional improvements and become mechanisms that present management models (INPI, 2015). The present article has the purpose of understanding how these patent deposits can assist in the systematization of managing creativity in companies. The focus of the research on patents is supported by the need to understand the tools or practical applications possible of being implemented in any company.

Scientometrics was used as a method for performing the research, with data collection from: PatentScope (WIPO) and Patent Inspiration (AULIVE) data-bases. The procedure was performed using the words: managing creativity as a source of research for the registry of patents using a 10-year time-frame, covering the period of 2004 to 2014. The data was processed using the Gephi 0.8.2 for construction and representation of the researched patent networks.

The main results of the study point to an understanding of the relations between authors and the patent deposit companies, codes and users and even of the relations of countries with codes, inventors and users. The analyses of the network help to understand the behavior of the patent deposits, as well as to the expansion in relation to researches in the area of managing creativity. The results suggest that companies with mechanisms for managing the creativity of their collaborators are able to develop innovations and, consequently, attain a competitive edge.

In this manner, this study complements the researches related to managing creativity within organizations. As managerial contribution the possibility of performing patent researches with the aim of verifying means of improvement in the organizational management processes is verified, once at present the studies on patents have essentially been suited as a source of research on technological innovations and minimally as a source of analysis of management of companies. In relation to theoretical contributions, we suggest discussing the use of patents for the systematization of organizational creativity management, as a constructive basis for the development of innovation.

In the section below the theoretical basis for the relation between Creativity, Innovation and Patents is presented. Subsequently the method used in this study shall be addressed, as well as the results obtained, a discussion of the results and final considerations on the study.

\subsection{Theoretical understanding of the term creativity}

\section{Literature Review}

Creativity has its concepts discussed throughout the last decades and there are countless proposals of concepts in literature. The word creativity originates from the Latin "creare", which means make, bring forth, produce. For Torrance (1976), creativity is related to sensitivity to problems, to deficiencies of knowledge, to the identification of difficulties and to the search for solutions, formulating propositions in relation to the problems and communication of results. Sternberg and Lubart (1999) consider that creativity is understood as an ability to produce an act that is new (original, unexpected) as well as appropriate (useful or adaptable to the difficulties of the tasks). In corroboration, Kaufmann (2003) emphasized that creativity refers to new ideas heightened by value and usefulness.

It is understood that the theoretical conception on the theme creativity refers to the context of original ideas offering value to the end user. According to Alencar (1995) creativity is a valuable resource, which needs to be nurtured, especially in times of changes and uncertainties generated by accelerated transformations of technologies, globalization and regional integrations of production and distribution, universalization of communication, as well as political and cultural changes. In this manner, the environment is perceived as influential for the development of creativity, as suggested by Gurgel (2006) who considers that creativity refers to multifactorial and multidimensional phenomena, in other words, individual, cognitive and psychosocial aspects, such as environmental influences over the process of creation.

According to Bruno-Faria (2003) the importance of creativity of individuals and groups should be emphasized as a driving source of innovation and of changes in organizations. For SanMartim (2014), creativity and innovation fulfill a decisive role in companies in the dynamic contemporary scenario, full of risks and uncertainties. For the author, the capacity and skill of creating is a precious asset. In this context, it is possible to observe a movement within companies in the search for mechanisms capable of optimizing individual and collective creativity of collaborators and transform these into possible innovations capable of producing a competitive edge.

\subsection{Managing creativity as a subsidy for innovation}

According to Woodman, Sawyer and Griffin (1993), organizational creativity can be defined as being the creation of something new, valuable or useful, being either a product, a service, an idea or a process. According to Gurteen (1998) creativity and innovation in the process of creation and application of new knowledge are considered as being the essence of knowledge management, and should thus be stimulated and developed. Amabile (1996) emphasizes that the characteristics of an environment favoring creativity include the 
perception of an organization open to new ideas and the acceptance of changes. Thus, the environment of interaction between individuals and the tools available can be the driving force of creativity and, consequently, of innovation. From a macro perspective, creativity and innovation are presently of vital importance to companies. For managing creativity, a favorable organizational context must be provided in order to obtain, maintain and stimulate the generation of ideas by individuals. Van Dijk and Van den Ende (2002) state that the system of suggestions is an important form for the generation of ideas, once it channels the creativity of employees, and offers support for the implementation of a culture of innovation. Martins and Terblanche (2003) stress that creative relationship is determined by the organizational culture from factors such as: strategy, structure, support mechanisms and level of communication and of incentive towards innovation. For the authors, standards and beliefs that guide the organization can support or hinder creativity and innovation.

According to Westwood and Low (2003) creativity is contained within the innovation process. For these authors innovation represents the practical application of creative ideas and, accordingly, a company is not capable of innovating if it does not have the capacity of generating and cultivating creative ideas within its teams. The complete individual creative process should be considered as an essential element in the process of organizational innovation, once it is the individual creativity that renders raw-material for innovation of the organization (Amabile, 2010). For Dobni (2008) recent interest for analysis of the culture of innovation is, in a certain manner, associated to the impacts generated on the performance of the organization, being considered an essential element to attain a competitive edge and reach the objectives related to return and competitive advantage.

As such, the creative process represents the formulation of original solutions to cope with the perspectives of new issues and challenges, arising from the constant changes in the global scenario. Abernathy and Clark (1985) stress that the different types of innovation require different types of organizational environments and different management skills or levels of creativity. Corroborating this point, George (2007) states that creativity is an essential means by which organizations and their member can create significant and lasting value in an environment of dynamic changes. Creativity is a necessary factor, although not sufficient, for innovation, whereby innovation of different types can improve national and global economic competitiveness by means of larger scales of production (SOUSA, 2010). Puccio and Cabra (2010) emphasize that two trends have fostered the increased research in the area of creativity: the need of organization to quickly adapt to changes; and the concern towards innovation as a generator of a competitive edge.

According to Leonard and Sensiper (1998) the levels of structured and disseminated knowledge in the organization determine the level of creativity and, consequently, of innovation within the organization. For Hertog (2000) in an economy based on knowledge what matters to the client in the products and services is how these will be capable of performing a facilitating role, attending to their requirements in an innovative manner. For the authors, the whole structure of the companies and their innovation processes should be mapped, generating performance based on knowledge and creativity for the client.

The relevance of companies developing mechanisms guided towards managing creativity in the organizational environment was verified in this context. Emphasis is given to the researches already performed on this matter in different countries, as well as patent deposits that can indicate management solutions to companies.

\subsection{The use of patents as a source of research}

For Haase, De Araújo and Dias (2009) knowledge is one of the most important aspects for attaining the growth of an organization and this knowledge, in turn, differs from other production factors due to its intangibility. For the authors, one of the ways of making knowledge more tangible is the registry of patents. Patents are a temporary title of ownership over an invention or utility model, granted by the State to the inventors or authors holding the right over the creation. The inventor or holder of the patent has the right of impeding third parties, without their consent, of producing, using, selling or importing the product object of their patent. Conversely, the inventor is obliged to reveal in details all the technical content of the patent (INPI, 2015). According to Quoniam, Kniess and Mazieri (2014) the patent is seen as the manner of expressing to the market a purely technical and technological investigation.

Callon, Courtial and Penan (1995) point out that companies use scientometric methods to determine the technological strategy followed by their competitors, detecting the scientific expertise that serves as a basis for their key-technologies. Barroso et al. (2003) point out that over 30\% of the patents on the Brazilian data-base become public within five to six years and around $40 \%$ is of public domain and can be freely and openly used like a technical and technological encyclopedia.

The relation between patent registries, innovation and technological acceleration according to Boldrin and Levine (2013) is not evidenced or proven in countries with higher incidence of deposits. Nevertheless, Quoniam, Kniess and Mazieri (2014) emphasize the usability of patents as a means for research in the field of Human and Social Sciences. The use of the International Patent Classification (IPC) is one of the main means 
of usage of knowledge, once it permits a functional understanding and of the application of the information contained in the patent. Studies related to the relation between patents and technological innovation, such as the studies of Patel and Pavitt (1997) and Archibugi and Pianta (1995) offered a great contribution to the understanding of the dynamics of technological changes and innovation. According to Canongia, Pereira and Antunes, 2002) the use of patents is being presented as a powerful tool and efficient instrument in the support of decision making due to the informational content. For these authors, this source of information permits the identification of relevant technologies, partnerships, market niches for action, incremental innovations and movements of competition. The patent becomes an object of practical use, susceptible to industrial application, presenting a new form or presentation, involving the inventive act, resulting in a functional improvement with its use or manufacture (INPI, 2015). In this manner, monitoring and systematic investigation of the contents of patent documents has become a fundamental strategy for the generation of knowledge and improved performance of companies.

\section{Method}

The present article is characterized as a descriptive study, once it analyzes indicators of patent deposits, aiming towards correlating these with managing creativity. For Locke, Silverman and Spirduso (2009) the descriptive research captures and demonstrates a scenario of an express situation in numbers in which the nature of the relation between variables is performed in a correlational research.

The technique used was scientometrics, defined as a study of the quantitative aspects of science as a discipline or economic activity. It involves quantitative studies of scientific activities, including publications and, therefore, overriding bibliometrics (Macias-Chapula, 1998). Scientometric techniques have been applied to conduct national and international analyses of scientific literature, where patent researches are included.

The object of the research is deposited patents in the 10-year period between 2004 and 2014. For data collection the PatentScope was used, a service for searching patents of the World Intellectual Property Organization (WIPO), that permits access to the technology contained in over 2.2 million international requests for patent deposits and 32.5 million including documents of patents of regional and national collections (WIPO). Another instrument used was Patent Inspiration (AULIVE), a patent data-base with over 69 million processes and patents of products worldwide. The first search was performed using the words managing creativity in the title or summary of patents. From the PatentScope there were 18,680 patents and on Patent Inspiration (AULIVE) 16,691 patents using the same search terms, considering for the research the results patents presenting the two terms together or separately. Considering that the objective of the research was to search for patents addressing the term managing creativity, a second search was made using "managing creativity" with the terms between quotation markets, in order to restrict the search. In this search on PatentScope 129 patents were identified and on Patent Inspiration 113 patents, respectively, corresponding to the sample of this research. After the research, PatentNet was used for the generation of a file and analysis of the data for preparation of the network with the use of the Gephi program, as demonstrated below.

\section{Results}

It is observed that the patent deposits containing the term managing creativity in the last ten years have been through constant changes and variations in quantities. Peaks of deposits can be verified in the years 2006, 2007 and 2011, accompanied by a decrease in the last two years 2013 and 2014.

Figure 1 - Patent deposit per year (until June 2014)
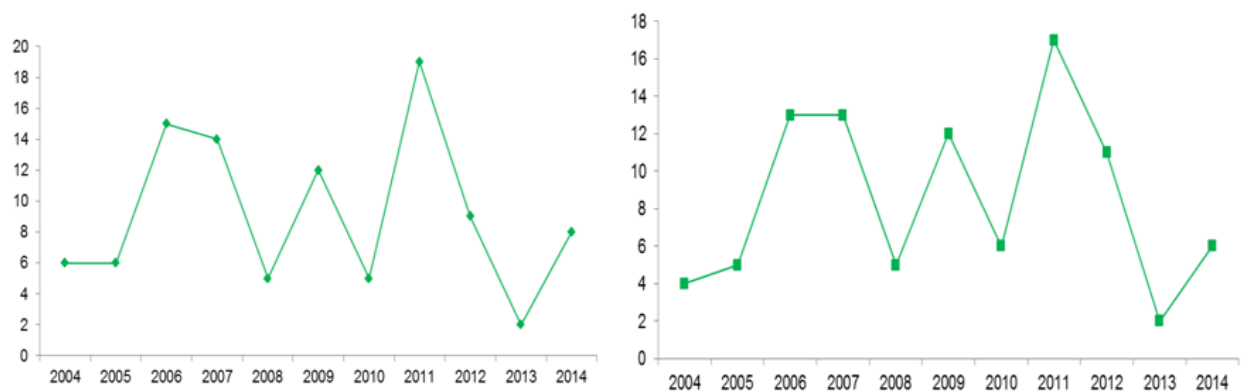

Source: research data - obtained on PatentScope (2016) and Patent Inspiration (2016)

In relation to the countries with the highest amount of patent deposits, it is observed that the United States of America is in first place in both sources of research, followed by countries from Europe, United Kingdom, France and Ireland. The PatentScope base presents data from the Patent Cooperation Treaty (PCT), of which 139 countries are members, and from the European Patent Office (EPO). 
Figure 2 - Countries with highest amount of patent deposits
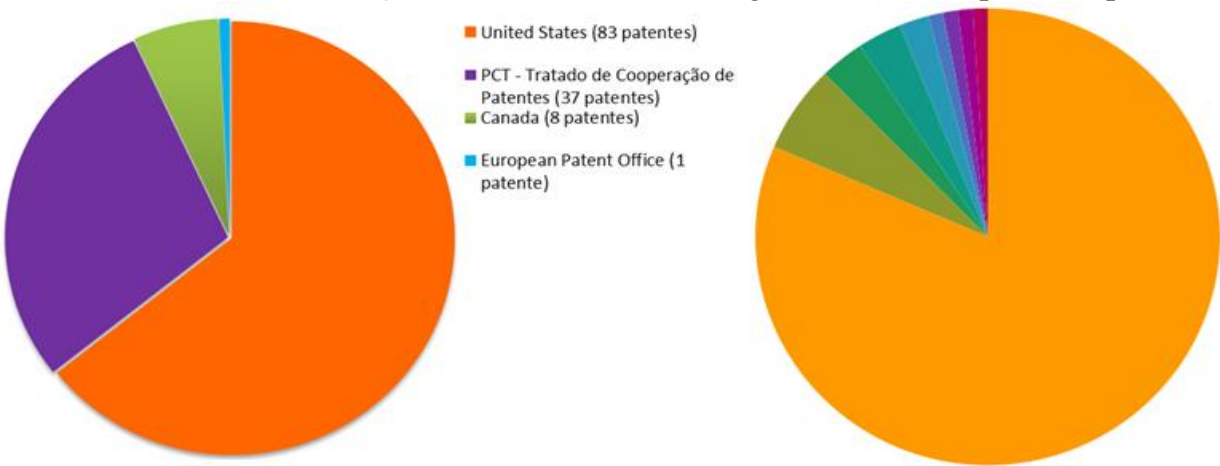

Enited States (79 patents)

Cnited Kingdom (6 patents)

IFrance (3 patents)

Ereland ( 3 patents)

EBelgium (2 patents)

Uapan (1 patents)

ECanada (1 patents)

India (1 patents)

Iswitzerland (1 patents)

Source: Research data obtained on PatentScope (2016) and Patent Inspiration (2016)

With reference to the applicant companies or users of the patents, a difference among the information of both data-bases is verified, although the first three companies remain the same. Yahoo is one of the greatest users, followed by Accenture LLP or Andersen Consulting LLP, a management consulting, information technology and outsourcing company, the world's largest consulting company (Wikipedia). In third place is AppNexus, with its head-office in New York, which offers a specialized platform on on-line publicity (Wikipedia).

Figure 3 - Main applicant
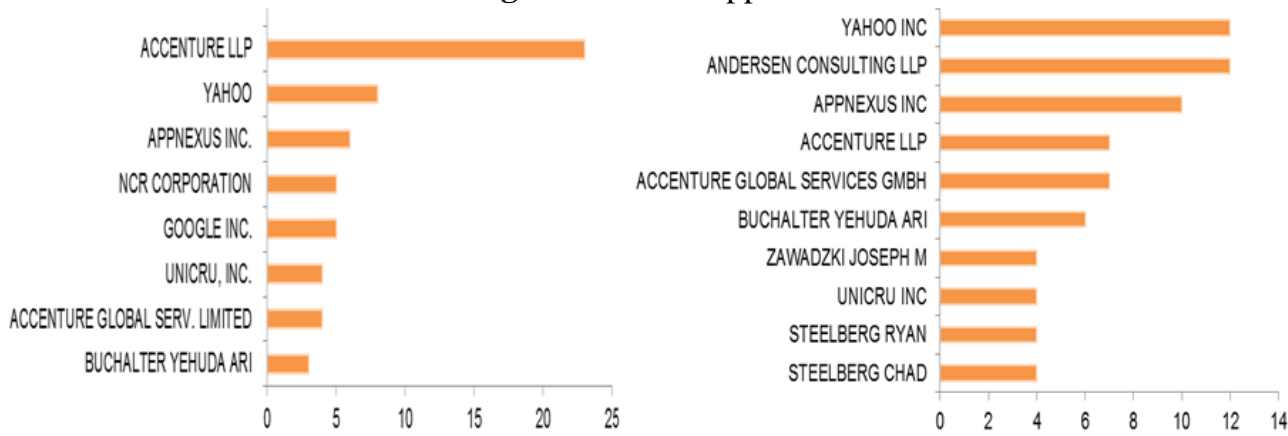

Source: Research data obtained on: PatentScope (2015) and Patent Inspiration (2016).

With reference to the applicant, in relation to the year of this registry, we observed a timeline from 1996 to 2014, where Anderson Consulting is observed in 2000 and 2001 with seven and five patents, respectively, and Yahoo, in 2007, with seven patents. The other companies presented similar information.

Figure 4 - Applicants versus Time

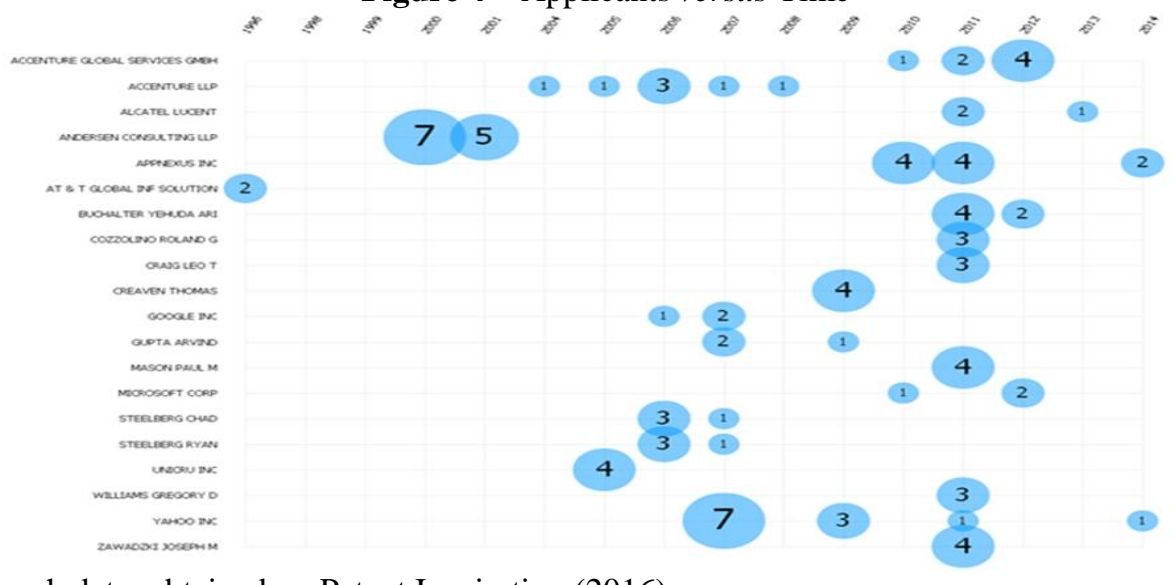

Source: Research data, obtained on Patent Inspiration (2016)

In terms of the main depositors or inventors, two names are highlighted in both bases. Gupta Arvind, Indian inventor and discloser of the science, where most of his patents are related to the code G06Q (data processing systems or methods) and the greatest applicant to his patents is Yahoo. The other inventor that stands 
out is Michael Guheen, where most of his patents are related to the code G06F (computer models) and the greatest applicant to these patents was Accenture Consulting. The employment relationship between the inventors and the companies using their patents was not evidenced in the research.

Figure 5 - Main inventors of patents
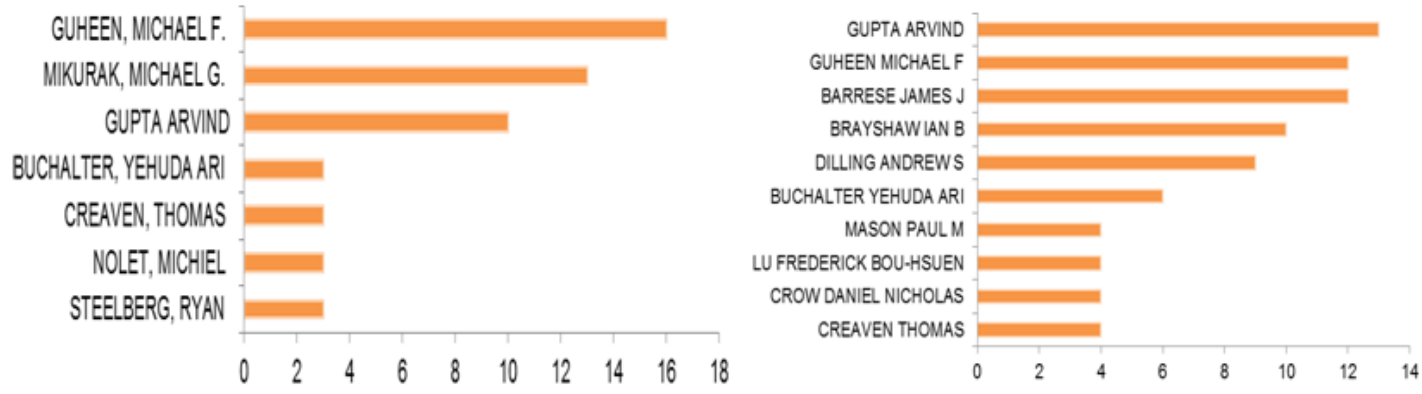

Source: Research data, obtained on: PatentScope (2016) and Patent Inspiration (2016).

Regarding the areas that mostly use the patents there are: trade industry and administration using the same initial code G06Q - data processing systems or methods. Subsequently, there is the area of digital computing, with the patent of initial code G06F - computer models. A considerable number of patents with the term managing creativity is evidenced in the administrative and commercial areas, as per Figure 6, confirming the assumption that patents can contribute to expand knowledge of the companies about tools or processes for the systematization of creative management.

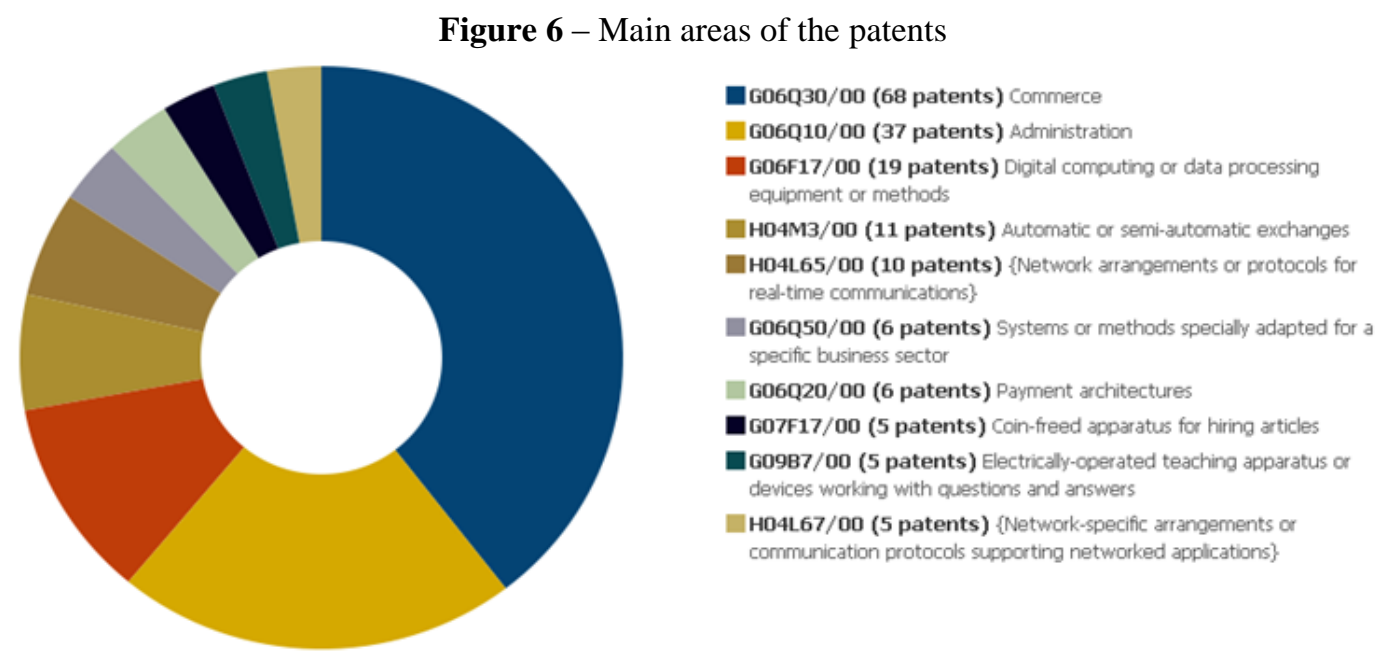

Source: Research data, obtained on: Patent Inspiration (2015)

The IPC - International Patent Classification presents the most common codes when the term creative management is researched. Accordingly, as previously observed, the code G06Q is the most commonly used and refers to data processing systems or methods, especially adapted for administrative, commercial or financial purposes. Code G06F is second, related to computer models. The remaining codes and their specifications are demonstrated under Table 1.

Figure 7 - IPC principal

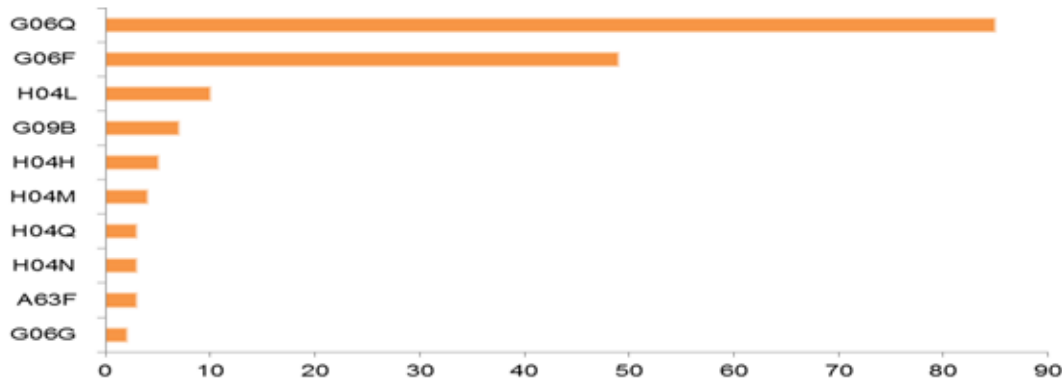

Source: Research data, obtained on: PatentScope (2015) 
Table 1 - Description of codes of patents for managing creativity:

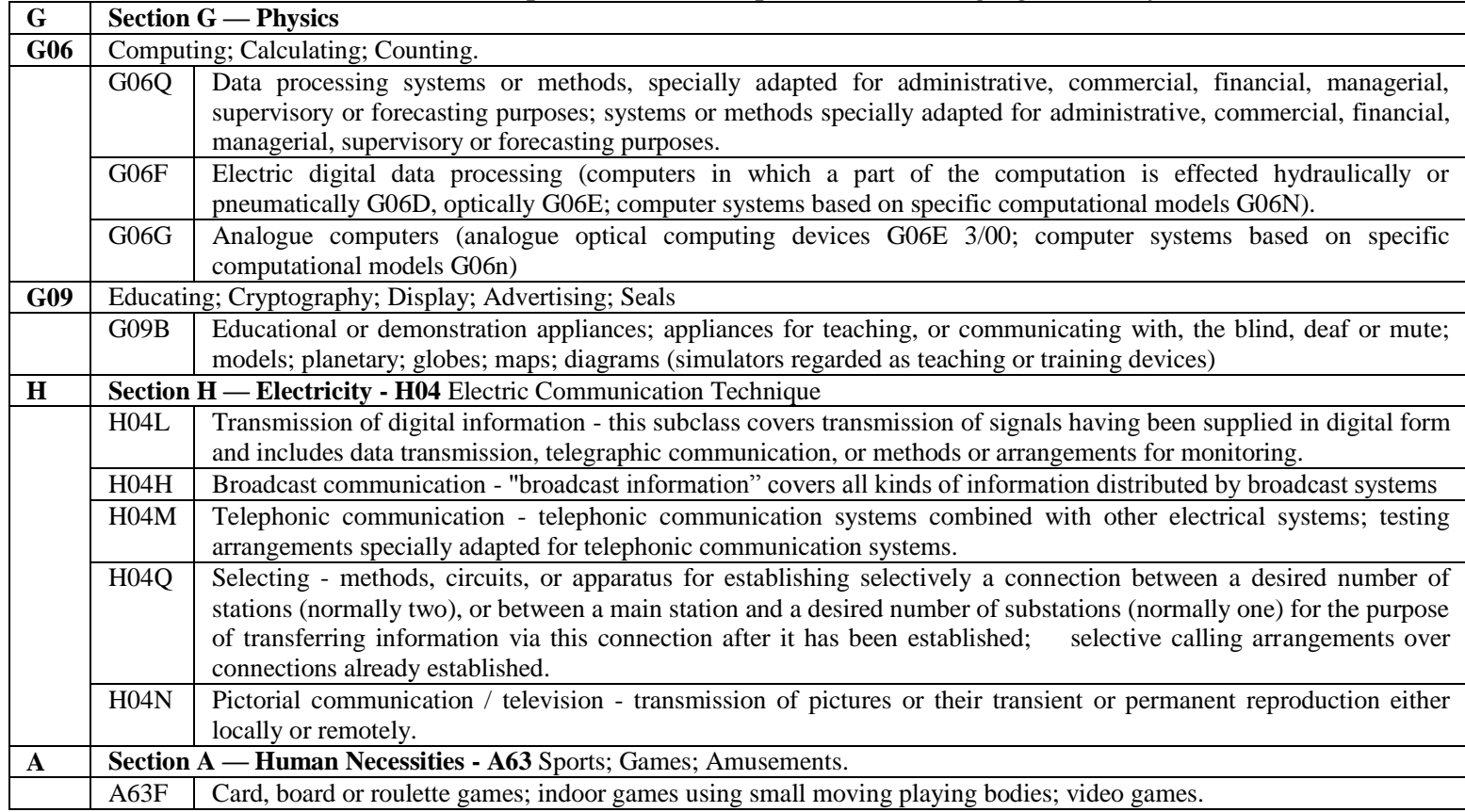

Source: International Patent Classification (IPC)

When the use of patent codes is analyzed throughout the last years, as per Figure 7, it can be observed that there is an emphasis in the use of code G06Q30/00 - trade industry: purchases or e-commerce, mainly in the years 2006, 2007 and 2011, consequently the years in which there was a higher number of patent deposits, as evidenced in Figure 1. There are other highlighted features, such as the use of code G06Q10/00 (administration and management) in the years 2006 and 2012. Subsequently, in 2007, the use of code G06F17/00 is observed digital computing or data processing equipment or methods, especially adapted for specific functions. It is also important to note in 2007 the use of code H04L65/00, which in the international classification is H04L29/06 or H04L29/08 - network arrangements or protocols for real-time communication and code H04M3/00 - telephone communication, automatic or semiautomatic exchange. When observing the applicants for patents, Figure 4, it is possible de verify Yahoo in 2007 and in 2011 a homogeneous distribution in 2011 among various companies.

Figure 8 - Use of patent codes versus period
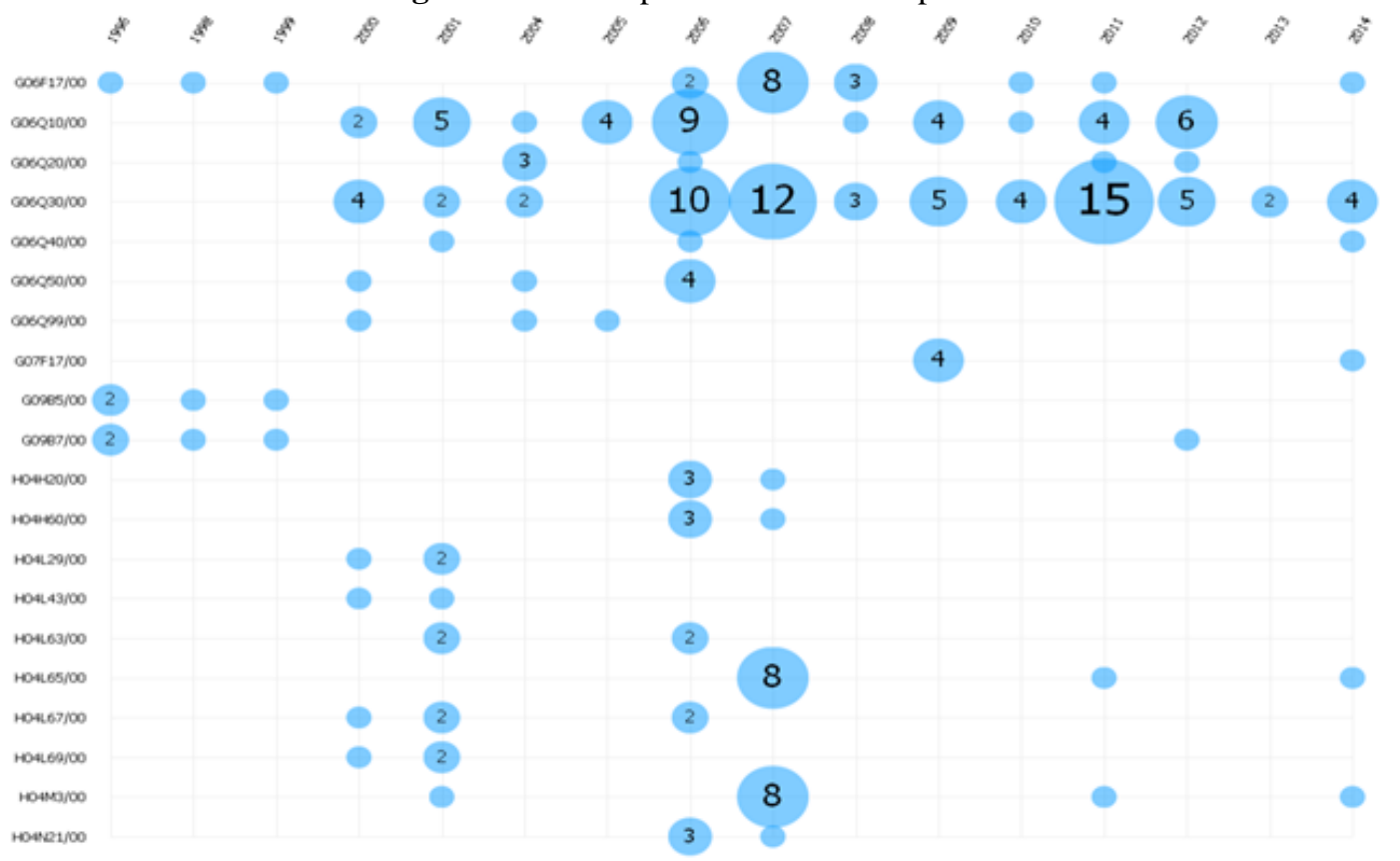

Source: Research data - obtained on Patent Inspiration (2016) 
With the aim of understanding the network of patents, a research was performed using PatentNet which resulted in 283 patents. From this information some collaboration networks were generated with the following information: inventor, International Patent Classification (IPC), applicant or user and country of the patent deposit. The use of these networks in this research had the purpose of understanding how the relations between inventors and patent applicants behave, as well as relations of these with the patent deposit countries and the IPC codes used, demonstrating a panorama of patent deposits in the 10-year research period. In Figure 9 the first map generated with the selected information is presented, where it is possible to observe some relationship blocks.

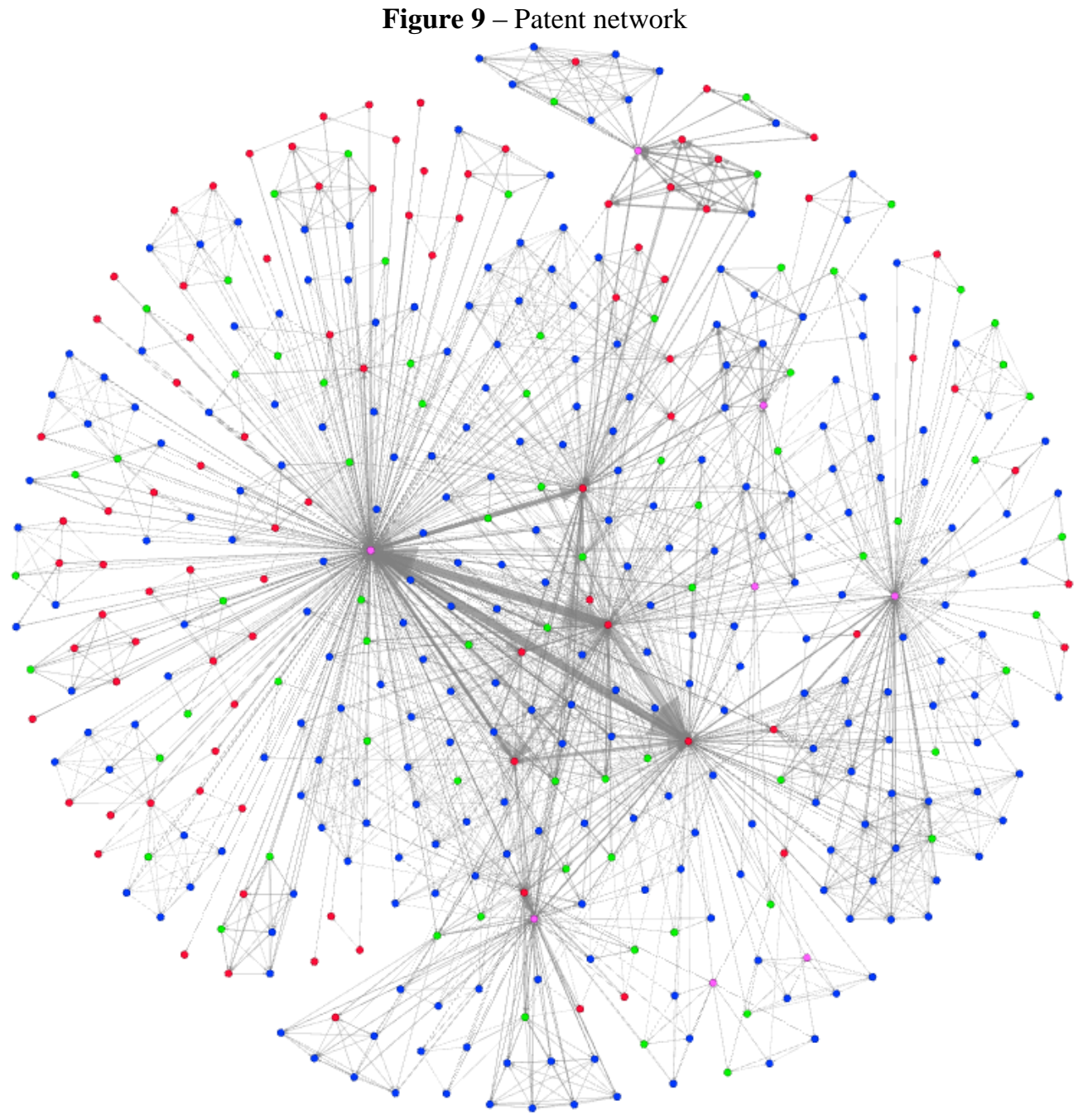

*: Blue: Inventor/Red: International Patent Classification (IPC)/Green: Applicant/Pink: country.

Source: Research data - prepared on Ghephi (2016)

Upon analysis of the patent network, some filters were made in order to understand the relations. First the network of applicants or users of patents was analyzed, where there was a greater homogeneity among networks. The relation between applicants in more than one country at the same time, as is the case of Mitsubishi Electric Corporation (SP and JP), Nipon Denso (SP and JP), Hitachi LTD. (JP; TW; WO), Fujitsu LTD (JP and WO), Elpida Memory INC (JP and US). The connection between companies is also observed, as is the case of the universities that are tied to the countries and to other companies, being intermediaries or holders of the patents. 


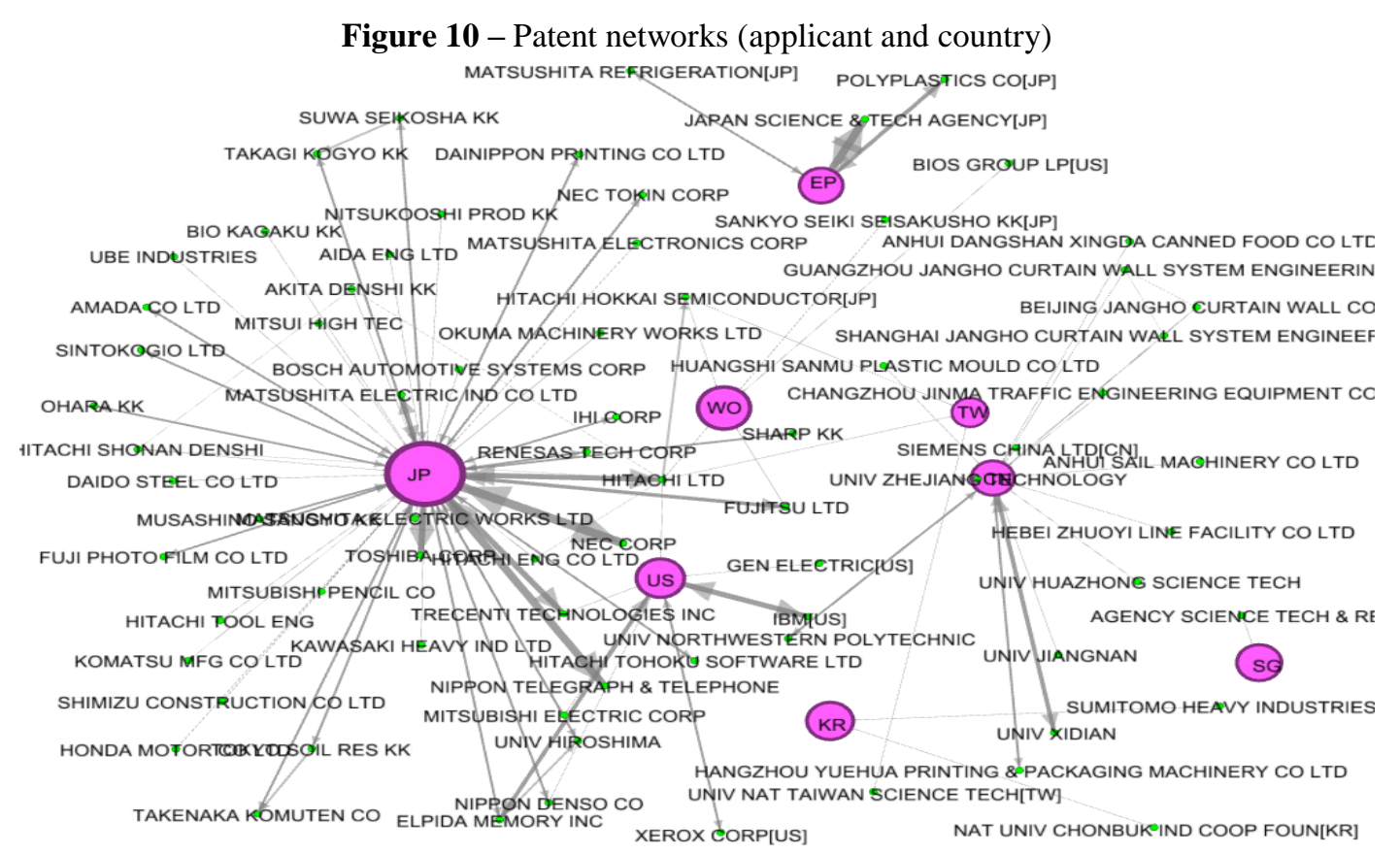

Source: Research data - prepared on Ghephi (2016).

In Figure 11 the network between inventors and countries is observed. It is possible to verify some networks in separate groups, such as, for example, small groups of inventors linked to the European Patent Office (EP), World International Property Organization (WO), Republic of Korea (KR), Singapore (SG), Taiwan (TW), United States of America (US). Nevertheless, two larger inventor networks are observed linked to Chine China $(\mathrm{CN})$ and to Japan (JP), these countries have the highest patent deposits in the world, together with the United States (US).

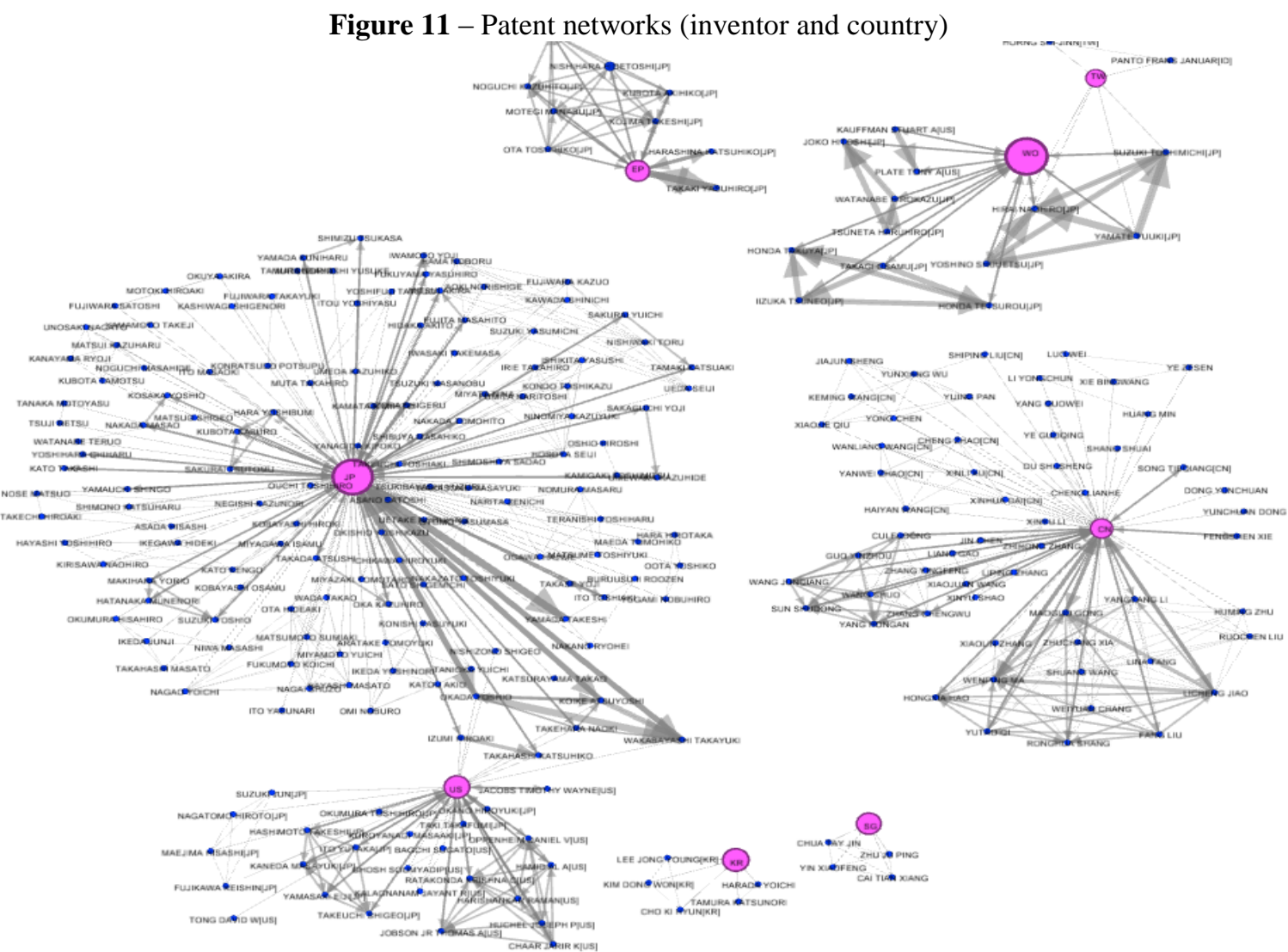

Source: Research data - prepared on Ghephi (2015) 
Upon analysis of the network between the applicant and the IPC code it is possible to observe the relation between the codes and the users that have relations with various codes, as is the case with some large companies, such as: Xerox Corporation US (G06F, G06Q, G06K, G06T), General Electric US (G06Q e G05B), IBM (G06F, G06Q, BM5G, G01C) and Toshiba Corporation (G06Q, G05B, B23Q). The most used codes for the term managing creativity are G06Q and G06F, with a strong relation between the various user companies and also with reference to other patent codes. The relation of the companies with the various codes is explained once these search for different technologies or processes to attend to their requirements, in this manner, the research in different areas can offer adequate solutions to their necessities.

Figure 12 - Patent networks (applicant and IPC)

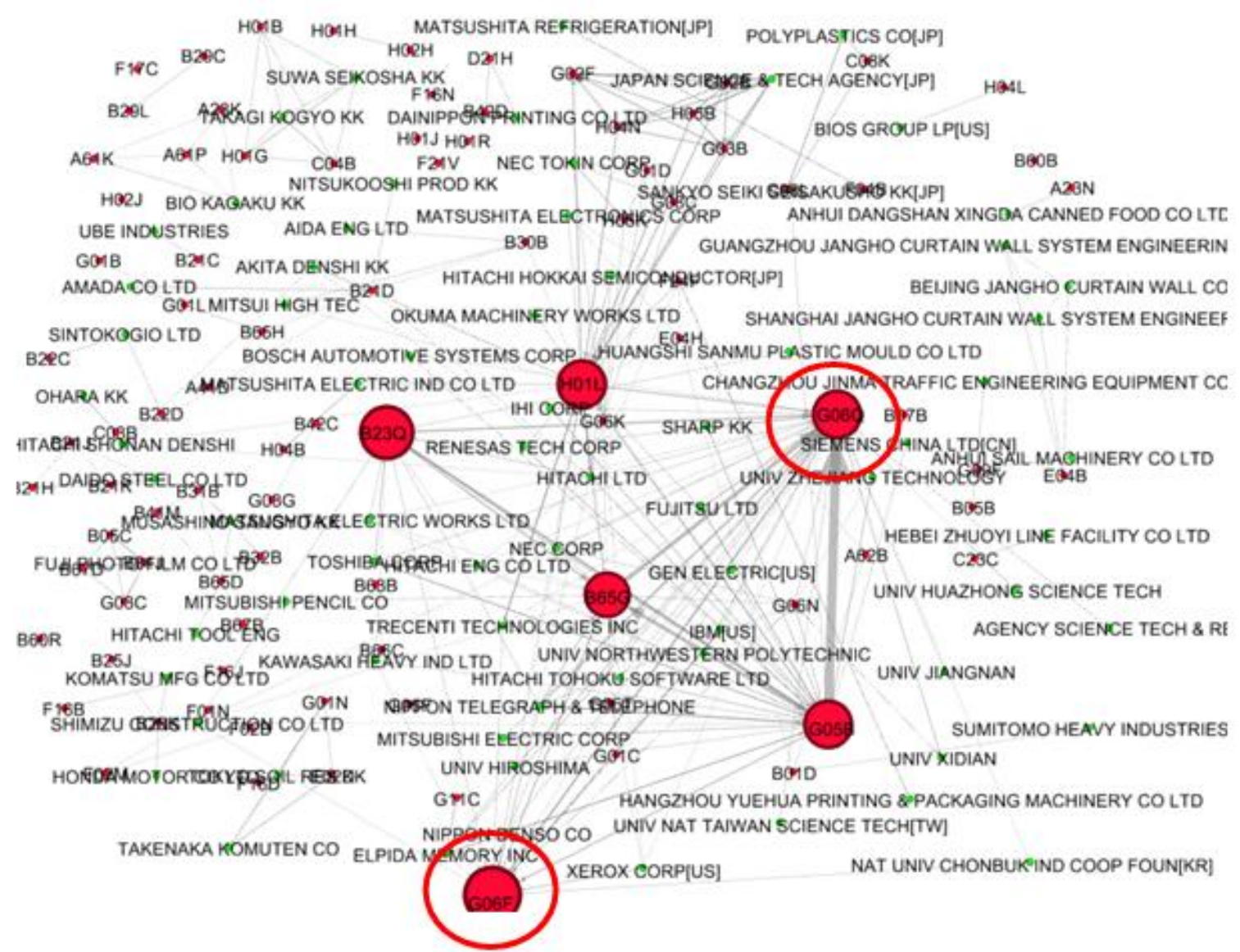

Source: Research data - prepared on Ghephi (2016)

As a last analysis of the networks there is the relation between the IPC codes and countries. An intense relation is observed in various codes with Japan (JP), this reflects the fact that Japan is one of the countries with the most patent deposits and in this manner builds relations and deposits in different areas.

Other countries that stand out are: China, the United States and the European Patent Office (EP) with strong relations and use of various IPC patent codes. Emphasis to some IPC codes is also observed, such as: G06F, G06Q, B65G, B23Q, H01L, which present strong relations among themselves. It is also possible to observe some countries that use only one or two codes, as is the case of Singapore (SG) which has relations only with code G06Q, Taiwan (TW) uses codes G06Q and H01L, and the Republic of Korea (KR) with codes G06Q, G06F and B01D. 


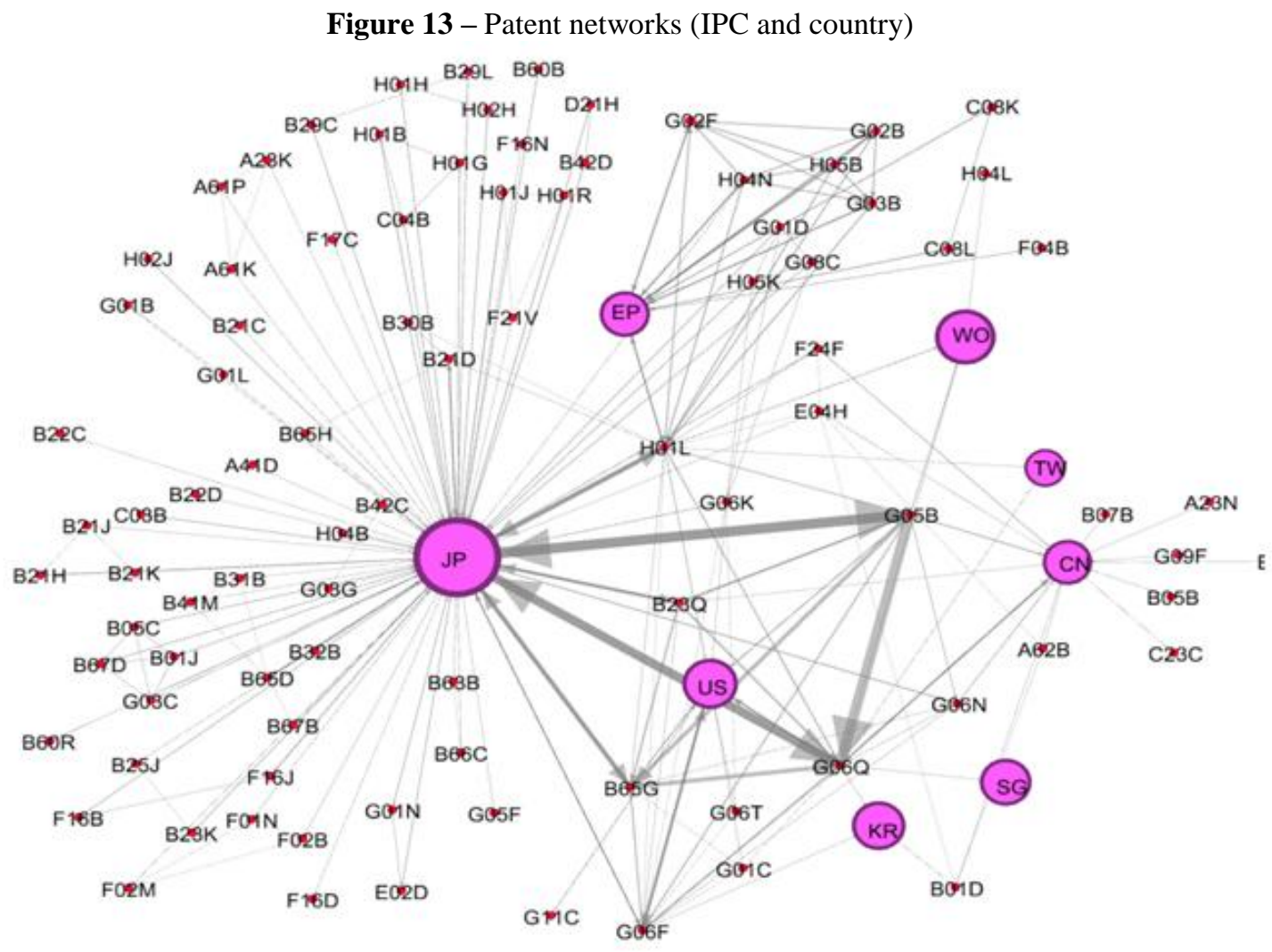

Source: Research data - prepared on Ghephi (2016)

Through the network analyses it is possible to understand the relations between authors and user companies of the patents, codes and users, and even the relations of countries and codes, inventors and users. The analyses aid in the understanding of the behavior of the patent deposits, as well as the increase in researches in the area of managing creativity.

\section{Discussions of Results and Final Considerations}

Upon conclusion of the research sustaining the present article, it is verified that patents can supply to companies the necessary support for the development of solutions and for managing creativity. The results of the research suggest that companies that have mechanisms for managing the creativity of their employees can develop innovations and, as a consequence, attain a competitive edge.

Through the analyses performed, some indicators of patent deposits related to the years of the research are verified, where it is possible to observe that as of 2012 there was a decline in patent deposits related to the term managing creativity. It is also possible to notice a higher number of deposits in relation to the countries, inventors and main users of patents. When verifying the areas that most use patents related to the term managing creativity, emphasis is given to the trade industry, where there are many patents related to the area of marketing, commerce and promotion of products. In second place there is the area of administration, which in the present study is the area of our interest. When observing the codes mostly used, the code G06Q stands out, which refers to data processing systems or methods, especially adapted for financial, administrative, surveillance purposes, or commercial and administrative planning.

In the search for a more detailed understanding about how patents can contribute for companies to be able to visualize management possibilities of their creative processes, an analysis of the patents researched on the PatentScope data-base (129 patents) was carried out. Since the same patents are also on the Patent Inspiration data-base, it was not necessary to verify this data-base. Accordingly, five patents were selected (Appendix A) where it is possible to verify systematization tools for managing creativity. One can mention the patent of Thieberger Gil (2006) which presents the corresponding methods and systems for the creation, sharing, dissemination, collection, tracking, development, filing and management of information related to: business objectives, creative ideas in coherence with specific business objectives and implementation of these creative ideas. The relation of the management of creative ideas linked to organizational objectives is emphasized in this patent, optimizing, in this manner, the results of the company and directing the efforts of human capital. 
The patent of Marc Devillard (2014) also stands out, which comprises a method for managing sessions managing collective creativity, in a computer environment that includes a server of the session and a diversity of participating terminals connected to a server through a network. The use of technology is verified as a support system for managing collective creativity, which is another focal point within companies at present. It was also noticed that managing collective creativity is increasingly used by large companies. When analyzing the networks, the relations between inventors and users, countries and users or inventors, codes used and their connections observed. Through the networks it was possible to understand the behavior of patent deposits.

Thus, the present study contributes towards researches related to managing creativity and the use of patents as a support in the management of companies. The originality of the research refers to patent research as a documental source for understanding management tools, because very little has been researched and published on patents in Brazil and in countries under development.

The limitations inherent to the research refer to the need for content analysis of the researched patents, verifying their whole structure and proposal. As a suggestion for future researches, emphasis is given to the importance of the research in patents in order to understand the tools for support to the management of companies, and in this manner, it is suggested that the research be expanded to patents of public domain.

As a management contribution the possibility of using the research on patents for searching for ways of improving organization management processes is verified, since at present the patents have served as a source of research for technological innovations and less so from a point of view of management of companies. In relation to theoretical contributions, we suggest discussions about the use of patents for the systematization of organizational creativity management, considered as a basis for the development of innovations.

\section{Referências}

[1]. Abernathy, W. J., \& Clark, K. B. (1985). Innovation: Mapping the winds of creative destruction. Research policy, 14(1), 3-22.

[2]. Alencar, E. L. S. (1995). Desenvolvendo a criatividade nas organizações: o desafio da inovação. Revista de Administração de Empresas, 35(6), 6-11.

[3]. Amabile, T. M. (1996). Creativity in context. Harper Collins: Oxford.

[4]. Amabile, T. M. (2010). The three threats to creativity. Harvard Business Review.

[5]. Archibugi, D., \& Michie, J. (1995). The globalisation of technology: a new taxonomy. Cambridge journal of Economics, 19(1), $121-140$

[6]. Barney, J. B. (1991). Firm resources and sustained competitive advantage. Journal of Management, 7(1), 99-120.

[7]. Barroso, W., Quoniam, L., Gregolin, J. A. R., \& Faria, L. I. (2003). Analysis of a database of public domain Brazilian patent documents based on the I PC. World patent information, 25(1), 63-69.

[8]. Boldrin, M., \& Levine, D. K. (2013). The case against patents. The journal of economic perspectives, 27(1), 3-22

[9]. Bruno-Faria, M. De F. (2003). Criatividade, inovação e mudança organizacional: teoria e gestão. Rio de Janeiro: Editora FGV, 111-142.

[10]. Canongia, C., Pereira, M. N. F., \& Antunes, A. (2002). Gestão da informação e monitoramento tecnológico: o mercado dos futuros genéricos. Perspectivas em ciência da informação, 7(2) 18-36.

[11]. Carvalho, A. O., Ribeiro, I., Cirani, C. B. S., \& Cintra, R. F. (2016). Organizational resilience: a comparative study between innovative and non-innovative companies based on the financial performance analysis. International Journal of Innovation, 4(1), 58-74.

[12]. Callon, M., Penan, J. P., Callon, H., Courtial, J. P., \& Penan, H. (1995). Cienciometría: la medición de la actividad científica: de la bibliometría a la vigilancia tecnológica. Trea.

[13]. Dobni, C. B. (2008). Measuring innovation culture in organizations: The development of a generalized innovation culture construct using exploratory factor analysis. European Journal of Innovation Management, 11(4), 539-559.

[14]. George, J. M. (2007). Creativity in Organizations. The Academy of Management Annals, 1(1), $439-477$.

[15]. Gurgel, M. F. (2006). Criatividade e inovação: uma proposta de gestão da criatividade para o desenvolvimento da inovação. Dissertação. (Mestrado em Ciências em Engenharia de Produção) - Universidade Federal do Rio de Janeiro.

[16]. Gurteen, D. (1998). Knowledge, creativity and innovation. Journal of knowledge Management, 2(1), 5-13.

[17]. Haase, H., De Araújo, E. C., \& Dias, J. (2009). Inovações Vistas pelas Patentes: Exigências Frente às Novas Funções das Universidade. Revista Brasileira de Inovação, 4(2), 329-362, jul/dez.

[18]. Hertog, P. D. (2000. Knowledge-intensive business services as co-producers of innovation. International journal of innovation management, 4(4), 491-528.

[19]. Instituto Nacional de Propriedade Industrial - INPI. Patente. Disponível em: <http://www.inpi.gov.br/portal/acessoainformacao/ artigo/patente_1351691647>. Acesso em: 02 dez. 2015

[20]. International Patent Classification (IPC). Official Publication (WIPO). Disponible in: 〈http://www.wipo.int/classifications/ipc/en/>. Acessed: 24 apr. 2016.

[21]. Kaufmann, G. The effect of mood on creativity in the innovative process. In: Shavinina, L. V. (Org.). (2003). The International Handbook on Innovation. Oxford: Elsevier Science, 191-203.

[22]. Leonard, D., \& Sensiper, S. (1998). The role of tacit knowledge in-group innovation. California management review, 40(3), 112132

[23]. Locke, L. F., Silverman, S. J., \& Spirduso, W. W. (2009). Reading and understanding research. Sage.

[24]. Macias-Chapula, C. A. (1998). O papel da informetria e da cienciometria e sua perspectiva nacional e internacional. Ciência da informação, 27(2), 39-54.

[25]. March, J. G. (1991). Exploration and exploitation in organizational learning. Organization science, 2(1), $71-87$.

[26]. Martins, E. C., (2003). Terblanche, Fransie. Building organisational culture that stimulates creativity and innovation. European journal of innovation management, 6(1), 64-74.

[27]. Patel, P., \& Pavitt, K. (1997). The technological competencies of the world's largest firms: complex and path-dependent, but not much variety. Research policy, 26(2), 141-156. 
[28]. Patent Inspiration. Aulive method. Disponble in: 〈https://app.patentinspiration.com/\#report/c159f06A0F58/filter〉. Acessed in: 30 mai. 2016.

[29]. Puccio, G. J., \& Cabra, J. F. Organizational creativity. In: Kaufman, J. C., \& Sternberg, R. J. (Ed.) (2010). The Cambridge Handbook of Creativity. Cambridge University Press, 145-173.

[30]. Quoniam, L., Kniess, C. T., \& Mazzieri, M. R. (2014). A patente como objeto de pesquisa em Ciências da Informação e Comunicação. Revista eletrônica de biblioteconomia e ciência da informação, 19(3), 243-268.

[31]. Sanmartim, S. M. (2014). Criatividade e inovação na empresa: do potencial à ação criadora. Editora Trevisan.

[32]. Sousa, J. C. (2010). Processo de inovação em abordagem multidisciplinar. Revista Eletrônica de Gestão Organizacional, 4(2).

[33]. Sternberg, R. J., \& Lubart, T. I. (1999). The concept of creativity: Prospects and paradigms. Handbook of creativity, 1, 3-15.

[34]. Torrance, E. P. (1976). Criatividade: medidas, testes e avaliações. São Paulo: Ibrasa.

[35]. Van Dijk, C., \& Van Den Ende, J. (2002). Suggestion systems: transferring employee creativity into practicable ideas. $R \& D$ Management, 32(5), 387-395.

[36]. Vanti, N. A. P. (2002). Da bibliometria à webometria: uma exploração conceitual dos mecanismos utilizados para medir o registro da informação e a difusão do conhecimento. Ciência da Informação, 31(2), 152-162.

[37]. Westwood, R., \& Low, D. R. (2003).The multicultural muse: culture, creativity and innovation. International Journal of Cross Cultural Management, 3(2), 235-259,

[38]. Woodman, R. W., Sawyer, J. E., \& Griffin, R. W. (1993). Toward a theory of organizational creativity. Academy of Management Review, 18(2), 293-321.

APPENDIX A - Table 1 - Examples of patents with tools for the systemization of managing creativity

\begin{tabular}{|c|c|c|c|c|c|c|}
\hline $\begin{array}{l}\text { Patent } \\
\text { Number }\end{array}$ & Code & Deposit & Title & Inventor & User & Summary \\
\hline $\begin{array}{l}\mathrm{WO} / 2014 / 0 \\
20537\end{array}$ & $\begin{array}{l}\text { G06Q } \\
10 / 10\end{array}$ & 02.06 .2014 & $\begin{array}{lr}\text { Method, system } \\
\text { and computer } \\
\text { server for } \\
\text { managing } \\
\text { collective } \\
\text { creativity } \\
\text { sessions }\end{array}$ & $\begin{array}{l}\text { Devillard, } \\
\text { Marc }\end{array}$ & $\begin{array}{l}\text { Motivatio } \\
\text { n Factory }\end{array}$ & $\begin{array}{l}\text { The present invention comprises a } \\
\text { method for managing collective } \\
\text { creative sessions, in an environment } \\
\text { that includes a session server and a } \\
\text { plurality of participant terminals } \\
\text { connected to the server through a } \\
\text { network. }\end{array}$ \\
\hline $\begin{array}{l}\text { US200902 } \\
65343\end{array}$ & G06F 7/06 & 10.22 .2009 & $\begin{array}{l}\text { Systems and } \\
\text { methods for } \\
\text { creative works } \\
\text { registration and } \\
\text { ownership } \\
\text { determinations }\end{array}$ & $\begin{array}{l}\text { McFarland } \\
\text { Graham R. }\end{array}$ & $\begin{array}{l}\text { Express } \\
\text { Digital } \\
\text { Graphics, } \\
\text { Inc. }\end{array}$ & $\begin{array}{l}\text { Systems and methods for registering } \\
\text { creative work. Associated property } \\
\text { information, digital impression and } \\
\text { creative work can be stored in a data } \\
\text { bank. }\end{array}$ \\
\hline $\begin{array}{l}\text { US200602 } \\
29893\end{array}$ & $\begin{array}{l}\text { G06F } \\
17 / 30\end{array}$ & 10.12 .2006 & $\begin{array}{l}\text { Systems and } \\
\text { methods of } \\
\text { partnering } \\
\text { content creators } \\
\text { with content } \\
\text { partners online }\end{array}$ & $\begin{array}{l}\text { Cole } \\
\text { Douglas } \\
\text { W. }\end{array}$ & $\begin{array}{l}\text { Hewlett- } \\
\text { Packard } \\
\text { Developm } \\
\text { ent } \\
\text { Company, } \\
\text { L.P. }\end{array}$ & $\begin{array}{l}\text { Systems and methods of partnering } \\
\text { between content creators and } \\
\text { partnering content online. }\end{array}$ \\
\hline $\begin{array}{l}\text { US200602 } \\
29993\end{array}$ & $\begin{array}{l}\text { G06F } \\
17 / 60\end{array}$ & 10.12 .2006 & $\begin{array}{l}\text { Systems } \\
\text { methods and } \\
\text { brokering } \\
\text { creative content } \\
\text { online }\end{array}$ & $\begin{array}{l}\text { Cole } \\
\text { Douglas } \\
\text { W. }\end{array}$ & $\begin{array}{l}\text { Cole } \\
\text { Douglas } \\
\text { W }\end{array}$ & $\begin{array}{l}\text { Systems and methods of brokering } \\
\text { creative content online. In an } \\
\text { exemplary implementation, a method } \\
\text { can include receiving creative } \\
\text { contents from a user in electronic } \\
\text { format. }\end{array}$ \\
\hline $\begin{array}{l}\text { US200601 } \\
67715\end{array}$ & $\begin{array}{l}\text { G06Q } \\
99 / 00\end{array}$ & 07.27 .2006 & $\begin{array}{l}\text { Method and a } \\
\text { corresponding } \\
\text { system for } \\
\text { creativity and } \\
\text { innovation } \\
\text { management }\end{array}$ & $\begin{array}{l}\text { Thieberger } \\
\text { Gil }\end{array}$ & $\begin{array}{l}\text { Thieberger } \\
\text { Gil }\end{array}$ & $\begin{array}{l}\text { Methods and corresponding systems } \\
\text { for creativity, sharing, dissemination, } \\
\text { collection, tracking, development, } \\
\text { filing and managing information } \\
\text { related to: business objectives, } \\
\text { creative ideas consistent with the } \\
\text { specific business objectives, and } \\
\text { implementation of these creative } \\
\text { ideas. }\end{array}$ \\
\hline
\end{tabular}

Source: research data (WIPO) 2016 